\title{
Penggunaan Media Sosial Pada Proses Pembelajaran Online Menggunakan Analisis Diskriptif Kuantatif
}

\author{
Winarti $^{1}$ \\ ${ }^{\text {I}}$ Program Studi Teknik Informatika, Fakultas Teknik, \\ Universitas Darul Ulum Jombang \\ ${ }^{1}$ winarti.winarti@undar.ac.id
}

\begin{abstract}
The development of knowledge in the field of information and communication technology has received positive support from the world of education. The development of computers and supporting software can help in the visualization of objects or abstract concepts. The online learning system is one of the information technology breakthroughs that offers flexibility in a learning system. In addition, online media is very effective in creating an open learning environment, therefore online learning media is needed. One of the media is Facebook and Telegram. The purpose of this development is to utilize Facebook and Telegram as a means of collaboration in the world of learning. In addition, it is also to determine the effectiveness of the interactions that occur in online learning. Facebook and telegram learning was developed as material for social media groups by utilizing websites, blogs, yahoogroups, virtual laboratories, and google as supporting programs. The advantage of Facebook is that it is equipped with chat facilities that provide other sites. Facebook is a place for teachers, students, and enthusiasts of thermochemistry to interact outside of the classroom. Facebook was developed to be used for learning group members without the presence of a teacher or instructor, can be accessed by group members at any time and costs are relatively affordable, and can support information technology-based network programs according to government programs
\end{abstract}

Intisari- Perkembangan ilmu teknologi informasi dan komunikasi mendapat dukungan positif dunia pendidikan. Perkembangan computer dan software pendukung dapat membantu dalam visualisasi benda-benda atau konsep abstrak. Sistem pembelajaran online merupakan salah satu terobosan teknologi informasi yang menwarkan fleksibel dalam sebuah sistem pembelajaran. Selain itu melalui media online sangat efektif dalam menciptakan lingkungan belajar yang bersifat terbuka oleh karena itu di butuhkan media pembelajaran yang bersifat online. Salah satunya media tersebut adalah facebook dan telegram Tujuan pengembangan ini adalah untuk memanfaatkan facebook dan telegram sebagai sarana kolaborasi dalam dunia pembelajaran. Selain itu juga untuk mengetahui keefektifan interaksi yang terjadi pada pembelajaran online . Pembelajaran facebook dan telegram dikembangkan untuk materi untuk Grup media social dengan memanfaatkan website, blog, yahoogroups, virtual laboratorium, dan google sebagai program penunjangnya. Keunggulan facebook adalah dilengkapi fasilitas chatting yang memberikan situs lain. Facebook ini merupakan tempat guru, siswa, dan para peminat termokimia berinteraksi di luar kelas. Facebook dikembangkan digunakan untuk member grup belajar tanpa hadirnya guru atau instruktur, dapat diakses member grup kapan saja dan biaya relatif terjagkau, dan dapat mendukung program jaringan berbasis teknologi informasi sesuai program pemerintah.

Kata Kuncii: Pembelajaran, online. Media sosial, Anaisis kuantittif.

\section{PENDAHULUAN}

Massive Open Online Course (MOOC) adalah sistem pembelajaran berupa kursus online secara dan terbuka dengan tujuan untuk memendapatkan partisipan yang banyak dan mengakses melalui web. Materi kursus tradisional berupa video, pembacaan dan pembahasan masalah, MOOCs menyediakan forum pengguna interaktif yang membantu untuk membangun komunitas mahasiswa, dosen, dan asisten pengajar. MOOCs merupakan perkembangan terbaru dalampendidikan jarak jauh (E-Learning). 
Perkembangan media sosial berjalan secara online dimana setiap pengguna dengan mudah berbagi dan bercerita dalam bentuk blog, jejaring sosial, wiki, forum dan dunia virtual. Tidak hanya komputer saja, tetapi media sosialpun dapat diakses melalui perangkat komunikasi lain misal, telepon genggam android dan telepon blackberry. Menurut Kaplan dan Haenlein (2010) mendefinisikan media sosial sebagai "sebuah kelompok aplikasi berbasis internet yang membangun di atas dasar ideologi dan teknologi Web 2.0 , dan yang memungkinkan penciptaan dan pertukaran isi pengguna yang dihasilkan" Media sosial adalah manusia biasa yang saling berbagi ide, saling bekerja sama dan berkolaborasi yang intinya adalah menggunakan media sosial sama dengan menjadikan kita menjadi diri sendiri . Komunikasi di internet itu cenderung searah, komunikasi di social media kini bersifat interaktif, terbuka dan memungkinkan orang untuk ikut berpartisipasi di dalamnya. Beberapa situs social media yang populer sekarang ini antara lain: Blog, Twitter, Facebook, Wikipedia, dan YouTube.

Keberhasilan sistem e-learning tergantung pada kemampuan mereka untuk secara otomatis mengambil dan merekomendasikan konten pembelajaran yang relevan sesuai dengan preferensi pelajar tertentu. Pengalaman belajar dan pilihan dinamis materi pendidikan yang disajikan kepada peserta didik dapat ditingkatkan dengan menggunakan teknik rekomendasi yang berbeda. Pendekatan yang diterapkan untuk menggabungkan lingkungan sosial dan penambangan pola yang berurutan untuk menghasilkan rekomendasi sumber belajar bagi peserta didik. Beberapa percobaan dilakukan untuk memverifikasi kegunaan metode hybrid (pembelajaran berbasis online) yang diusulkan dalam lingkungan $e$ learning dan menganalisis teknik pemberian tag sosial yang dipilih [1]
Perkembangan yang mencolok dibandingkan dengan layanan adalah jejaring sosial atau social network. Jejaring sosial umumnya dikaitkan dengan nilai-nilai, visi, ide, teman dan lainnya . Facebook itu sendiri awalnya didirikan oleh seorang mahasiswa dari Universitas Havard, Mark Zuckerberg dengan tujuannya membuat sebuah jejaring sosial tersebut yang pada mulanya hanya terbatas pada mahasiswa havard saja, namun kemudian keanggotaan diperluas hingga ke perguruan lain seperti Boston, Ivy League, dan Universitas Stanford. Seiring dengan kepopulerannya di berbagai perguruan tinggi, kemudian menerima keanggotaan dari mahasiswa di universitas lain.

\section{LANDASAN TEORI}

Pengiklanan diinternet dan facebook dapat mempengaruhisikap dan perilaku seseorang. Dibuktikan dengan penilitian [2] yang melakukan survey untuk mempelajari metivasi individu muda terhadap internet, facebook. Terhadap 2 studi kasus penggunaan yaitu :

1. Penggunaan fitur facebook yaitu utilitas interpersonal dimana motivasi paling menonjol yang mempengaruhi peserta dari semua proses sikap dan perilaku. Dalam studi kasus yang pertama menganalisa dalam berpartisipasi dalam diskusi, menjadi bagian dari grup, bertemu dengan orang baru, dengan kata lain penggunaan iklan internet dan media sosial membawa pengaruh terkait terhadap sikap dan perlaku konsumen.

2. Para peserta yang mempunyai pendapat dan sikap positif terhadap penggunaan facebook cenderung menggunakan semua fitur facebook. Dari keseluruan menghasilkan bahwa kualitas hidup, pengaruh teman sebanyak dan waktu yang secara terstuktur dan signifikan mampu memprediksi penggunaan keduanya (fitur komunikasi satu ke banyak yaitu pembaruan status dan grup) dan fitur komunikasi satu ke satu 
(seperti perpesanan dan obrolan pribadi). Konsentrasi terhadap keamanan facebook diabaikan, karena semakin banyak pengguna merasa aman dan kurang memperhatikan privasi, maka semakin banyak pengguna melakukan melakukan proses interaksi dengan facebook.

Penelitian berikut oleh [3] yang meneliti tentang kepahaman tentang MOOC, (Massive Open Online Course) adalah kelas yang disampaikan dalam lingkungan online. MOOCs merupakan pendekatan sistem untuk pendidikan online. Efektivitas MOOCs adalah sebuah pertanyaan terbuka karena tingkat penyelesaian secara substansial kurang terhadap pembelajaran konvensional. Tujuan penelitian ini adalah untuk mengindentivikasi factor-faktor yang meningkapkan niat individu untuk terus menggunakan MOOCs, seperti sejumlah penelitian yang sebelunya telah dieksplorasi. Model penilitian ini berdasarkan informasi dengan model "Continuance Expectation - Confirmation". Model diusulkan dan di uji dengan data yang d kumpulkan dalam suatu penilitian secara besar. MOOC direferensikan karena dirasakan keterbukaan dalam penggunaan yang merasa puas terhadap aplikasi ini.

Massive Open Online Course (MOOC) Sebuah Massive Open Online Course (MOOC) adalah sistem pembelajaran berupa kursus online secara besarbesaran dan terbuka dengan tujuan untuk memungkinkan partisipasi tak terbatas dan dapat diakses melalui web. Selain menyediakan materi kursus tradisional seperti video, pembacaan dan pembahasan masalah, MOOCs juga menyediakan forum pengguna interaktif yang membantu dalam membangun komunitas untuk mahasiswa, dosen, dan asisten pengajar (TA). MOOCs merupakan perkembangan terbaru dalam hal pendidikan jarak jauh (e-Learning).

Seperti yang dikatakan [4] mengindikasikan, "Pendidikan terbuka, pengetahuan terbuka, dan sumber terbuka adalah wajah yang berbeda dari revolusi Web 2.0 dalam pendidikan tinggi. "Teknologi Web 2.0 memberdayakan situs web hari ini institusi pendidikan tinggi dengan cara yang hebat. Ada gerakan yang tumbuh dalam pendidikan tinggi untuk menciptakan materi kursus yang tersedia untuk digunakan tanpa batasan hak cipta atau menggunakan biaya. Gerakan ini sering mengacu pada materi yang dikembangkan dengan cara ini sebagai "Open Course Ware" (OCW) atau "Open Educational

Sumber daya “(OER). Istilah Sumber dari Open Educasition Resources (OER) mengacu pada "bahan digital yang ditawarkan secara bebas dan terbuka untuk pendidik, siswa dan pembelajar mandiri untuk digunakan dan digunakan kembali untuk pengajaran, pembelajaran, dan penelitian "(OECD, 2007).

Studi ini meneliti pengaruh pemantauan diri dan jumlah penggunaan Facebook di Kecanduan Facebook, dan asosiasi di antara pemantauan diri, kecanduan Facebook, Penggunaan Facebook, dan dukungan sosial. Desain crosssectional digunakan untuk mengumpulkan data dari 257 mahasiswa yang telah menggunakan Facebook. Temuan menunjukkan bahwa selfmonitors yang tinggi lebih cenderung kecanduan Facebook daripada monitor diri yang rendah. Di selain itu, jumlah teman dan aktivitas Facebook adalah prediktor utama darijumlah waktu di Facebook. Monitor diri yang tinggi, aktivitas Facebook, dan jumlah waktu prediksi kecanduan Facebook. Apalagi jumlah teman dan self-monitor rendah terkait dengan dukungan sosial.( 2017 Universitas Kasetsart. Layanan penerbitan oleh Elsevier B.V. Ini adalah akses terbuka artikel di bawah lisensi CC BY-NC-ND. [8]

Apa yang dimaksud dengan Telegram? Pengertian atau definisi arti dari Telegram adalah sebuah aplikasi gratis sebagai pengirim pesan atau messenger yang berbasiskan Cloud-based dimana semua datanya langsung disimpan di 
server secara cepat dan aman. Tentang nama Telegram, nama yang hampir mirip dengan Instagram. Kenapa kedua aplikasi tersebut memiliki persamaan pada pelafannya? Karena nama Instagram juga mengambil kata telegram sebagai salah satu kata pembentuknya. Sebenarnya nama Instagram adalah gabungan antara dua kata, yaitu instan dan telegram. Sedangkan aplikasi Telegram Messenger mengambil nama asli dari Telegramitusendiri.Apakah telegram dan aplikasi telegram mempunyai manfaat atau fungsi yang sama? Secara umum dan berdasarkan sejarah, Telegram dikenal sebagai pesan atau informasi yang dikirim melalui alat bernama Telegraf, dimana proses pengirimannya menggunakan kode Morse. Tarif Telegram lebih murah jika dibandingkan dengan tarif telepon. Hal itu yang membuat Telegram menjadi populer pada tahun 1920. Sedangkan aplikasi Telegram dikeluarkan pada tahun 2013 oleh para pembuatnya, yaitu 2 bersaudara Nikolai Durov dan Pavel Durov.

\section{METODE PENELITIAN}

Jumlah Anggota grup (JVM User group) 3315 yang bergabung Pembahasan seputar JAVA pada grup JVM member biasanya bertanya-tanya atau mengershare permasalahan yang dialami pada java. Bisa tukar pikiran bersama member lain untuk membantu memecahkan masalah.

Jumlah anggota grup (kotlin indonesia) 2480 orang yang bergabung Disini kita sama-sama belajar tentang Kotlin Indonesia, disini membahas tentang hasil kompilasinya dalam bentuk biakode JVM atau Javascript. Selain itu Kotlin ini dibuat oleh praktisi industri, bukan dari pihak akademis, sehingga lebih memahami kebutuhan yang diperlukan. Misalnya permasalahan umum seperti Null Pointer Excption yang sudah ditambahkan pada bahasa pemrograman ini. Dan pertimbangan terakhir yaitu, Kotlin tidak memerlukan cost untuk diadopsi, dengan dukungan mumpuni dari JetBrains, semua kode Java dapat langsung dikonversi ke dalam kode Kotlin hanya dengan satu klik, ditambah lagi.

Jumlah Anggota grup (LibreOffice.ID) 234 orang yang bergabung Grup ini membahas tentang customize update dan setting libre dan biasanya membuat logo.

Jumlah anggota grup (kali linux indonesia) Orang yang anggota yang bergabung, grup ini berdiskusi tentang keamanan (security) kususnya bagi pengguna distro Kali Linux Indonesia. Grup facebook paguyuban petani buah tin ini membahas tentang tanaman tin dan membahas macammacam pupuk organik lainnya.

1. Grup hidroponik jombang membahas menanam tanaman menggunakan pipa.

2. Grup komunitas petani unggul ini membahas tentang bertani yang berkwalitas dan berdiskusi tentang hasil bumi dan bercocok tanam

3. Grup belajar memasak ini berdiskusi tentang proses memasak dan aneka resep masakan

Penggunaan Facebook mengandung tiga pertanyaan pengukuran durasi penggunaan Facebook, jumlah waktu di Facebook, dan jumlah teman di Facebook. Facebook kegiatan mengandung depalan item yang menanyakan seberapa sering peserta melakukan aktivitas seperti mengobrol di Messenger dan posting pesan dan gambar di Timeline. Skala yang dberkisar dari:(1) Tidak pernah sampai (4) Selalu. Delapan item Aktivitas Facebook menerima nilai Cronbach 0,65 (SD 1/4 3.45. Pemantauan diri Mark Snyder (1974) digunakan untuk mengukur pemantauan diri peserta menyesuaikan perilaku mereka untuk kelayakan atau sejauh mana dan di mana peserta menyesuaikan perilaku mereka untk kelayakan situasi sosial. Skala itu berisi 25 item dengan jawaban "Ya" dan "Tidak" (misalnya, "Saya punya dianggap 
sebagai penghibur "dan" Saya hanya bisa berdebat ide yang sudah saya yakini”). Untuk skor peringkat, Snyder (1974) menyarankan bahwa monitor diri yang tinggi akan memiliki skor antara 13 dan 25, sedangkan monitor diri rendah akan memiliki skor antara 0 dan 12 . Skala yang diterima nilai diterima nilai Cronbach0,60 0,60 (SD 1/4 3,61). Kecanduan Facebook Versi singkat dari uji Kecanduan Internet (Young, 1998) diadaptasi untukmengukur Facebook peserta kecanduan. Para peserta diminta untuk memikirkannya pengalaman penggunaan Facebook mereka berkaitan dengan delapan pertanyaan (misalnya, “Apakah Anda merasa perlu menggunakannya Facebook dengan peningkatan jumlah waktu utuk mencapai kepuasan?"). Young (1998) menyatakan bahwa ada orang yang menjawab "Ya" hingga lima atau lebih dari delapan pernyataan akan diklasifikasikan sebagai pengguna yang kecanduan. Itu skala menerima nilai Cronbach 0,67 (SD 1/4 1,80). Dukungan sosial dioperasikan sejauh ini yang dirasakan seseorang dekat dengankeluarga, teman, dan rekan kerja. Weesse (2001) Social Support Strength Index disesuaikan untuk mengukur dukungan sosial peserta. Itu skala terdiri dari tiga item dan berkisar dari (1) Tidak Tutup sama sekali untuk (5) Sangat Dekat (misalnya, "Baru-baru ini, seberapa dekat (secara interpersonal, tidak secara geografis) menurut Anda bersama teman-teman”). Karena keandalannya rendah, satu itemdihapus. Dua item menerima keandalan yang dapat diterima $\left(\operatorname{SD~}^{1 / 4} .74\right.$, Croncbach a $1 / 4.71)$.

\section{UJI COBA}

Pada halaman home administrator dapat mengubah data dan menghapus data.

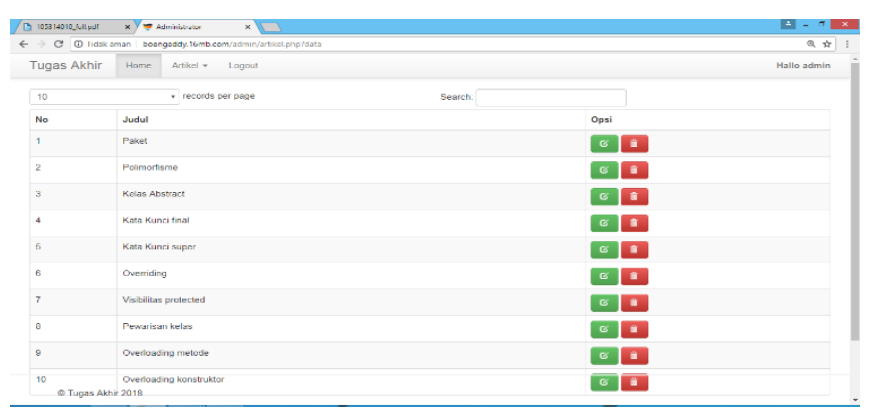

Gambar 1. Halaman Home

Pada menu ini user dapat melihat materi-materi yang diupload oleh administrator

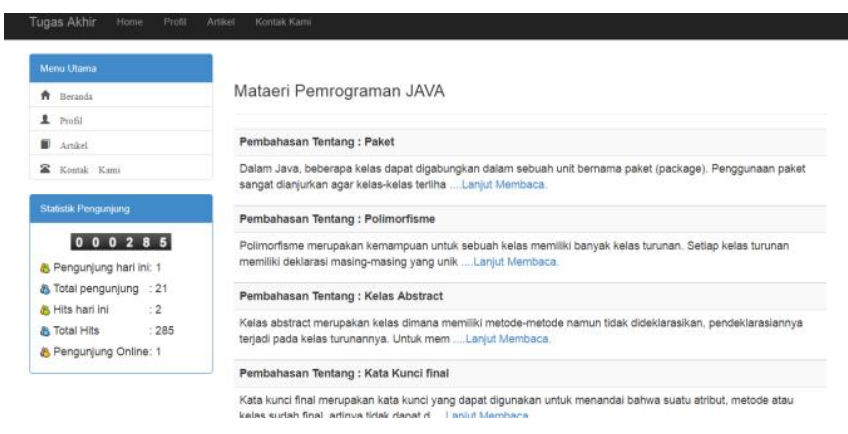

Gambar 2. Halaman Materi

Ketika user mengklik salah satu icon media social maka artikel akan otomatis tershare atau terbagikan ke social media tersebut.

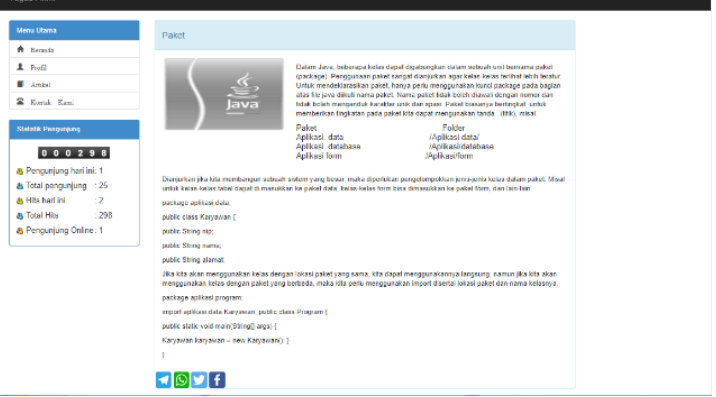

Gambar 3. Halaman Isi Materi 
User mengklik icon ini maka otomatis artiket akan di share atau dibagikan via telegram

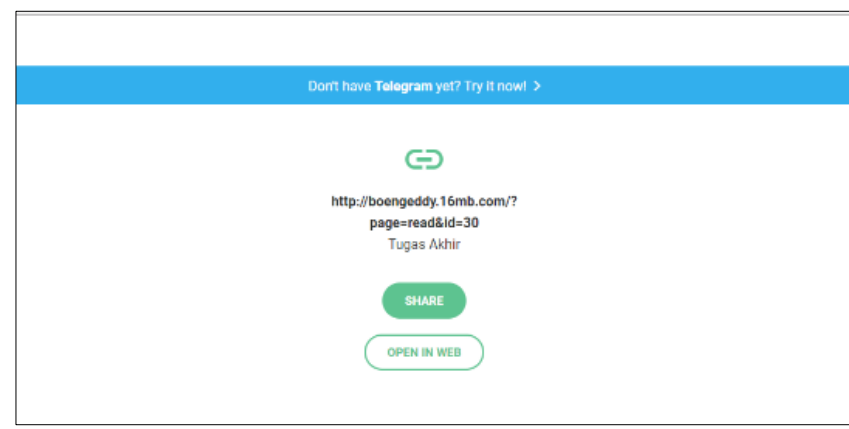

\section{Gambar 4. Share Whatsapp}

Ketika user mengkik icon, maka otomatis artikel di share atau dibagikan ke facebook.

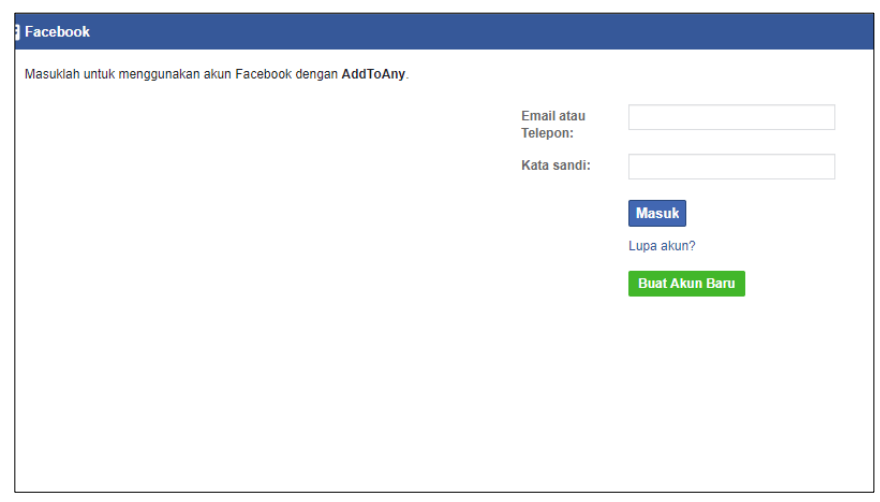

Gambar 5. Share Facebook
Tabel 1. Kuisioner Kualitas Sistem

\begin{tabular}{|c|c|c|c|c|c|}
\hline \multirow{2}{*}{ No } & \multirow{2}{*}{ Pertanyaan } & \multicolumn{4}{|c|}{ Jumlah Penilaian } \\
\hline & & SB & B & $\mathrm{C}$ & $\mathrm{K}$ \\
\hline 1 & $\begin{array}{l}\text { Apakah tampilan antarmuka aplikasi } \\
\text { web share materi pada grub sudah } \\
\text { menarik? }\end{array}$ & $31 \%$ & $46 \%$ & $23 \%$ & $0 \%$ \\
\hline 2 & $\begin{array}{l}\text { Apakah semua fungsi } \\
\text { (Tombol/Pilihan) dapat dijalankan? }\end{array}$ & $43 \%$ & $31 \%$ & $23 \%$ & $3 \%$ \\
\hline 3 & $\begin{array}{l}\text { Apakah aplikasi ini dapat membantu } \\
\text { pengguna dalam memperoleh media } \\
\text { informasi dengan mudah? }\end{array}$ & $29 \%$ & $37 \%$ & $34 \%$ & $0 \%$ \\
\hline 4 & $\begin{array}{l}\text { Apakah apikasimudah digunakan } \\
\text { secara keseluruhan? }\end{array}$ & $29 \%$ & $37 \%$ & $34 \%$ & $0 \%$ \\
\hline 5 & $\begin{array}{l}\text { Bagaimana kinerja saat menjalakan } \\
\text { aplikasi ini? }\end{array}$ & $37 \%$ & $46 \%$ & $14 \%$ & $3 \%$ \\
\hline 6 & $\begin{array}{l}\text { Apakah fitur aplikasi ini sudah dapat } \\
\text { memberikan manfaat seperti yang } \\
\text { diinginkan? }\end{array}$ & $34 \%$ & $40 \%$ & $20 \%$ & $6 \%$ \\
\hline \multicolumn{2}{|c|}{ TOTAL = Hasil Penjumlahan \% : 6} & $34 \%$ & $40 \%$ & $25 \%$ & $2 \%$ \\
\hline
\end{tabular}

\section{Kesimpulan}

Aplikasi pembelajaran media social untuk member grub berbasis web selesai dapat berjalan dengan baik dan sesuai dengan yang diharapkan. Aplikasi pembelajaran dibangun dengan menggunakan bahasa pemrogram dan PHP, serta menggunakan MySQL sebagai database penyimpanan medianya:

\section{REFERENSI}

[1] D. U. Bolliger, S. Supanakorn, and C. Boggs, "Computers \& Education Impact of podcasting on student motivation in the online learning environment," Comput. Educ., vol. 55, no. 2, pp. 714-722, 2010.

[2]H. H. Yang, "New World, New Learning: Trends and 
Issues of E-Learning,” Procedia - Soc. Behav. Sci., vol. 77, pp. 429-442, 2013

[3] K. H. Lau, T. Lam, B. H. Kam, M. Nkhoma, J. Richardson, and S. Thomas, "The role of textbook learning resources in e-learning: A taxonomic study," Comput. Educ., vol. 118, pp. 10-24, 2018.

[4] K. M. Alraimi, H. Zo, and A. P. Ciganek, "Understanding the MOOCs continuance: The role of openness and reputation," Comput. Educ., vol. 80, pp. 28-38, 2015.

[5] M. G. Moore, “Theory of transactional distance," 1997.

[6] M. Schophuizen, K. Kreijns, S. Stoyanov, and M. Kalz, "Eliciting the challenges and opportunities organizations face when delivering open online education: A groupconcept mapping study," Internet High. Educ., vol. 36, no. March 2017, pp. 1-12, 2018.

[7] T. Batson, "Why is Web 2.0 Important to Higher Education?," /campustechnology.com, 2009. [Online]. Available:

https://campustechnology.com/Articles/2009/04/15/Why -Web-2.0-is-Important-to-Higher-

Education.aspx ?Page $=2$

[8]V. Pornsakulvanich, "Excessive use of Facebook: The influence of self-monitoring and Facebook usage on social support," Kasetsart J. Soc. Sci., vol. 39, no. 1, pp. 116-121, 2017. 